\title{
Glaucoma and generics in Europe
}

Jaskra i leki generyczne w Europie

Anton Hommer, PhD

Private Office, Vienna, Austria



H I G HLIGHTS

There is a significant difference between approving generic topical glaucoma medications and systemic generics. No bioequivalence studies are required for glaucoma drops

\section{N A J W A Ż N I E J S Z E}

Istnieje znacząca różnica między miejscowymi oryginalnymi lekami przeciwjaskrowymi a lekami generycznymi ogólnoustrojowymi. Nie są wymagane badania biorównoważności w przypadku kropli przeciwjaskrowych.

\section{ABSTRACT}

Original drugs and generic drugs used in glaucoma differ from each other. This can lead to worse drug tolerability and, as a result, to worse patients' compliance. Therefore, an essential issue is, besides the drug's efficacy, its optimal tolerability for the patient. The potential differences in viscosity, $\mathrm{pH}$, drop size, and surface tension has a potential strong influence on the complex delivery mechanism of the active molecule to the receptors in the eye and its clinical relevant efficacy. These differences, in addition to different appearance and handling of a "new" bottle, may pose problems with patients' compliance after using a new preparation.

Key words: compliance, bioavailability, eye drops, benzalkonium chloride, timolol

\section{STRESZCZENIE}

Oryginalne leki i leki generyczne stosowane w jaskrze różnią się od siebie. Może to prowadzić do gorszej tolerancji na leki i w rezultacie do pogorszenia przestrzegania zaleceń przez pacjentów. Dlatego istotną kwestią jest, oprócz skuteczności leku, jego optymalna tolerancja ze strony pacjenta. Ewentualne różnice w lepkości, pH, wielkości kropli i napięciu powierzchniowym mogą mieć istotny wpływ na dostarczanie aktywnej cząsteczki do receptorów w oku i jej klinicznie istotną skuteczność. Różnice te, poza różnym wyglądem i obsługą „nowej” butelki, mogą powodować problemy z przestrzeganiem zaleceń przez pacjentów w przypadku zastosowania nowego preparatu.

Słowa kluczowe: compliance, biodostępność, krople do oczu, chlorek benzalkoniowy, tymolol 


\section{THE ROLE OF GENERIC DRUGS IN THE TREATMENT OF GLAUCOMA}

Europe has more than 740 million inhabitants, 24 official languages and about 48000 ophthalmologists. At least at the moment there are countless variations in European healthcare systems, which can be centralized or decentralized, fully tax-funded or co-paid by the patients.

Moreover, patients' options in choosing the hospital/doctor/medication, etc., vary from country to country and the situation is even more complicated when we acknowledge that there are "non-profit" vs. private hospitals. Obviously, all this, along with different life expectancy (e.g., for men in Latvia: 68 years, in Sweden 80 years), have a significant impact on the patients' care.

But one thing is very similar all over Europe: the rising role of generics in glaucoma treatment.

Glaucoma is a group of eye diseases (mostly bilateral) which causes damage to the optic nerve head and can lead to vision loss. Glaucoma is the second leading cause of blindness in Europe. The conversion from diagnosis to at least unilateral blindness is more than $1 \%$ per year.

According to the relevant glaucoma guidelines, medical therapy is the first-line treatment of most types of glaucoma. Since the diagnosis of open angle glaucoma, which is by far the most frequent type of glaucoma in Europe, is frequently made at the age between 55 and 65 years, we have to forecast at least 25 years of therapy.

Due to the increasing life expectancy and therefore the rising number of people with age-related diseases, glaucoma treatment becomes a more and more important part in ophthalmology. In addition, early disease diagnosis and better evaluation of its progression lead to more treatment.

As a result, in the last years the costs of glaucoma treatment have become particularly relevant. For decades, $\beta$-blockers were drugs of first choice in glaucoma treatment. In the 1990s, prostaglandin analogues (PGAs) replaced $\beta$-blockers and became the most commonly prescribed class of IOP-lowering medication due to their once-daily dosing, superior IOP-lowering efficacy, and better tolerability. The first generic PGA was approved in March 2011. Since then, generic glaucoma medications have become increasingly popular.

\section{What is the situation in Europe?}

In 2015 we evaluated the status of glaucoma diagnostics and care in Europe. In 18 European countries that responded generic glaucoma medications are present on the market. In only 2 out of 18 countries physicians can prescribe the molecule, otherwise they need to choose the brand name. In no country the dispending person is allowed to switch within the group to the similar molecule (e.g., dispense latanoprost instead of tafluprost; "out simile rule"). In only 4 out of 18 countries physicians are not pressured by the healthcare authorities to prescribe more generic products. In all countries patients have to make at least a co-payment for their glaucoma medications. No country provides free glaucoma medications.

\section{But can we use generic glaucoma drops as easily as other generics?}

Due to several facts, the similarity or differences in topically applied ophthalmic solutions compared to oral or systemic medications should be reviewed critical.

\section{What is a generic medication?}

According to the FDA (Food and Drug Administration) definition: A generic drug is a medication created to be the same as an already marketed brand-name drug in dosage form, safety, strength, route of administration, quality, performance characteristics, and intended use. These similarities help to demonstrate bioequivalence, which means that a generic medicine works in the same way and provides the same clinical benefit as its brand-name version. In other words, you can take a generic medicine as an equal substitute for its brand-name counterpart.

\section{But is this all we need to know? Is a generic drug really the "same" or rather "similar"?}

Systemic medications (e.g. tablets, medications administered intravenously) have to undergo so-called bioequivalence studies, which are usually conducted in healthy volunteers (e.g., no glaucoma patients) in a cross-over design. Normally, serum and/or plasma samples are obtained at regular intervals and assayed for parent drug concentration. According to regulations applicable in the European Economic Area, 2 medicinal products are bioequivalent if they are pharmaceutically equivalent or considered pharmaceutical alternatives if their bioavailabilities after administration in the same molar dose are similar to such a degree that their effects, with respect to both efficacy and safety, are essentially the same. This is considered demonstrated if the $90 \%$ confidence intervals ( $90 \% \mathrm{CI}$ ) of the ratios for $\mathrm{AUC}_{0-\mathrm{t}}$ and $\mathrm{C}_{\max }$ between the 2 preparations lie in the range of $80-125 \%$.

Bioequivalence data for serum or plasma concentrations are usually not available for topically administered glaucoma medications. Therefore, glaucoma generics are usually on the market without providing any data from randomized clinical trials about their efficacy and tolerability, as it is required from brand name drugs.

\section{SOME SPECIFIC CHALLENGES FOR GLAUCOMA MEDICATIONS}

Most people with glaucoma have no symptoms or signs in the early and moderate stages of the disease. But instead 
the therapy in form of drops can do so. Viscosity, pH, drop size, etc., can differ between the brand name drops and their generic equivalents, which can lead to better or worse drug tolerability and, as a result, to better or worse patients' compliance. It is a well-known fact that reduced compliance is the major risk factor for glaucoma progression. Therefore, an essential issue is, beside drug's efficacy, its optimal tolerability for the patient.

A recent study from Germany has evaluated the interchangeability of the commercially available latanoprost drugs and their generic equivalents taking into consideration the concentration of the active substance as well as the preservative benzalkonium chloride. Authors observed the deviating reduction of the active substance as well as fluctuations of the drops mass. The concentration of benzalkonium chloride was mostly increased. The $\mathrm{pH}$ of the original drug and the generic was similar; however, there was a significant difference in $\mathrm{pH}$ as compared to the unpreserved formulation. In addition, due to font size, the packaging leaflet was illegible for people with impaired vision.

Another study showed that storage temperature has a significant influence on maintaining the concentration of the active molecule. A reduction of $10 \%$ within 30 days of storage at $25^{\circ} \mathrm{C}$ was observed. In another study Mammo et al. reported that viscosity, drop size, surface tension and bottle design differ significantly between brand name glaucoma drops vs. their generic equivalents.

\section{Excipients}

Ophthalmic drugs pose special formulation challenges to manufacturers: In general, formulators must pay attention to tonicity, $\mathrm{pH}$, stability, viscosity and sterility, as well as microbiological purity that has to be assured also during time of use. Some excipients do not need a justification or a specification if they are "well-known" or have been used in similar medicinal products. Therefore, they are not mentioned on the package leaflet. However, these excipients can influence osmolarity or $\mathrm{pH}$. For instance, it is commonly known that the concentration of benzalkonium chloride (BAK) in glaucoma drops can have a significant effect on drops tolerability and ocular surface. This is particularly important for patients with pre-existing ocular surface disease, which is a frequent problem in the same target group: the elderly patients. In addition, there is an increased risk of failure in glaucoma surgery depending on duration and concentration of BAK exposure before surgery. There is a significant difference in the concentration of BAK among different glaucoma drops. Even if the active molecule is the same, the concentration of BAK can differ 1:4 (fig. 1).

\section{Packaging, drop size, physical characteristics}

The majority of people believe that generics are more or less identical to the original branded products. But is this true? In Toronto, a group of ophthalmologists looked at it in more detail. They evaluated 11 different types of glau-

\begin{tabular}{|c|c|c|}
\hline Generic (Trade Name) & Manufacturer & Preservative \\
\hline Betaxolol (BetopticSSuspension) ${ }^{1}$ & Alcon & $0.01 \%$ benzalkonium chloride \\
\hline Bimatoprost (Lumigan 0.03\%) ${ }^{2}$ & Allergan & $0.005 \%$ benzalkonium chloride \\
\hline Bimatoprost (Lumigan $0.01 \%)^{3}$ & Allergan & $0.02 \%$ benzalkonium chloride \\
\hline Brimonidine (Alphagan) ${ }^{1}$ & Allergan & $0.005 \%$ benzalkonium chloride \\
\hline Brimonidine with Purite (Alphagan* $P)^{1}$ & Allergan & $0.005 \%$ stabilized oxychloro complex \\
\hline Brinzolamide (AZOPT Suspension) ${ }^{1}$ & Alcon & $0.01 \%$ benzalkonium chloride \\
\hline Brinzolamide/Timolol (AZARGA ${ }^{\otimes}$ Suspension) ${ }^{4}$ & Alcon & $0.01 \%$ benzalkonium chloride \\
\hline Dorzolamide (Trusopt) ${ }^{1}$ & Merck \& Co. & $0.0075 \%$ benzalkonium chloride \\
\hline Dorzolamide/Timolol(Cosopt $)^{1}$ & Merck \& Co. & $0.0075 \%$ benzalkonium chloride \\
\hline Latanoprost (Xalatan) ${ }^{1}$ & Pfizer & $0.02 \%$ benzalkonium chloride \\
\hline Levobunolol (Betagan) ${ }^{1}$ & Allergan & $0.005 \%$ benzalkonium chloride \\
\hline Timolol (Timoptic) ${ }^{1}$ & Merck \& Co. & $0.01 \%$ benzalkonium chloride \\
\hline Timolol (Timoptic-XE) $)^{1}$ & Merck \& Co. & $0.012 \%$ benzododecinium bromide \\
\hline Travoprost (TRAVATAN Solution) ${ }^{5}$ & Alcon & $0.015 \%$ benzalkonium chloride \\
\hline Travoprost (TRAVATAN Z ${ }^{\oplus}$ Solution) ${ }^{6}$ & Alcon & SofZia ${ }^{\bullet}$ Preservative System (contains multiple compounds)* \\
\hline Unoprostone (Rescula) ${ }^{1}$ & Novartis & $0.015 \%$ benzalkonium chloride \\
\hline
\end{tabular}


coma drops to find out a significant difference in drop size (fig. 2), viscosity and surface tension (fig. 3).

Timolol is usually given twice daily as monotherapy. A different formulation with so-called "thixotropic effect" was developed to reduce the frequency of its dosage to more convenient - once a day. Commercially, it was called Timoptic XE. Thixotropy is a time-dependent shear thinning property. Certain fluids or gels become more fluid when shaken. Then, after some time, they return to a more viscous condition. This process is known from the ketchup bottle phenomenon (when we shake the bottle before using). In such eye drop formulations blinking changes the viscosity of the medication and provides better resorption of the active molecule. It is obvious that viscosity and surface tension are particularly relevant in these formulations. Nevertheless, significant differences were found in these formulations. Certainly, there are differences in the daily dosing of the medication (fig. 4).

\section{FIGURE 2}

\section{Average drop volume in different generics [7].}



\section{FIGURE}

3

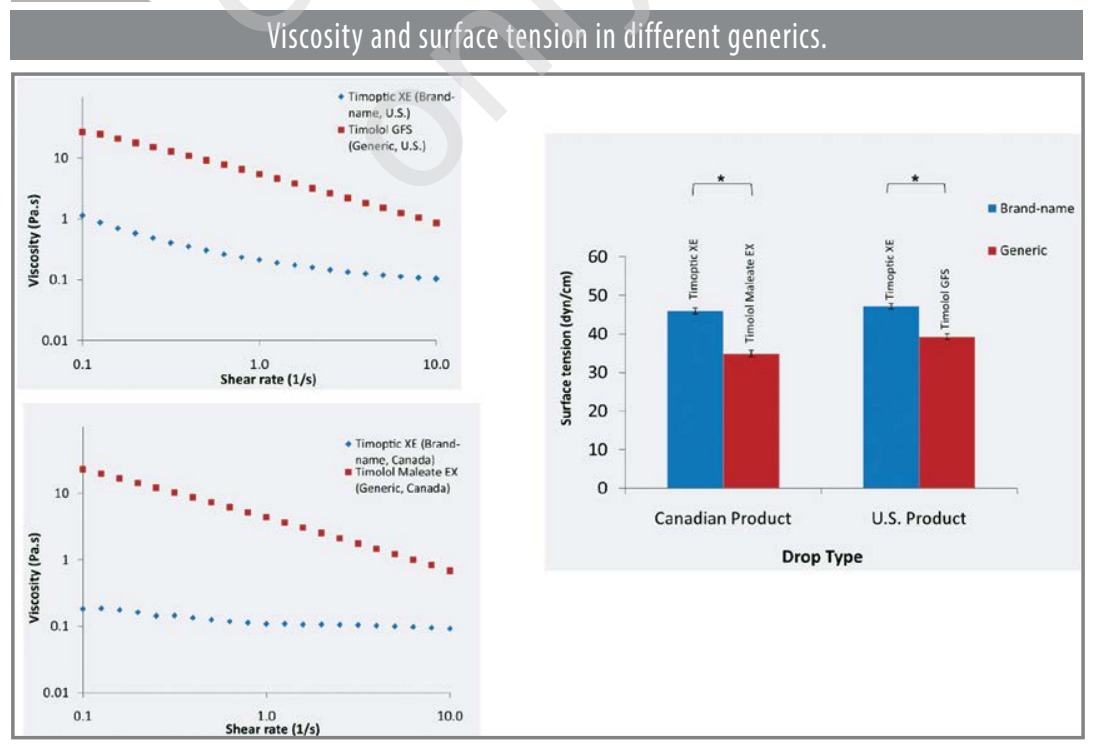


Differences in the daily dosing between generics [7].

\begin{tabular}{|c|c|c|c|c|}
\hline $\begin{array}{l}\text { Product name (country of } \\
\text { production) }\end{array}$ & $\begin{array}{c}\text { Active } \\
\text { ingredient'formulation }\end{array}$ & $\begin{array}{l}\text { Manutacturer's recommended } \\
\text { number of drop } \\
\text { instillations (NDI) }\end{array}$ & $\begin{array}{l}\text { Mean drop volume } \cdots \\
(\mathrm{MDV})(\mu \mathrm{L})\end{array}$ & $\begin{array}{c}\text { Average daily } \\
\text { prescribed dosage }=\mathrm{SO} \\
(\mathrm{NDI} \times \mathrm{MDV})(\mathrm{mg})\end{array}$ \\
\hline Timoptic XE (Canada) & $\begin{array}{l}\text { Timolol maleate } 0.5 \% \\
\text { solution }(6.8 \mathrm{mg} / \mathrm{mL})\end{array}$ & 1 drop daily & $42=4.0$ & $0.29 \pm 0.03^{\circ}$ \\
\hline Timolol maleate EX (Canada) & $\begin{array}{l}\text { Timolol maleate } 0.5 \% \\
\text { solution }(6.8 \mathrm{mg} / \mathrm{mL})\end{array}$ & 1 drop daily & $25=2.0$ & $0.17 \pm 0.01$. \\
\hline Timoptic XE (U.S.) & $\begin{array}{l}\text { Timolol maleate } 0.5 \% \\
\text { solution }(6.8 \mathrm{mg} / \mathrm{mL})\end{array}$ & 1 drop daily & $38=3.1$ & $0.26 \pm 0.02^{*}$ \\
\hline Timolol GFS (U.S.) & $\begin{array}{l}\text { Timolol maleate } 0.5 \% \\
\text { solution ( } 6.8 \mathrm{mg} / \mathrm{mL})\end{array}$ & 1 drop dalily & $24 \pm 1.5$ & $0.16 \pm 0.01$. \\
\hline Timoptic (Canada) & $\begin{array}{l}\text { Timolol maleate 0.5\% } \\
\text { solution ( } 6.8 \mathrm{mg} / \mathrm{mL})\end{array}$ & 2 drops dally & $28 \pm 1.4$ & $0.38 \pm 0.02^{* *}$ \\
\hline Apo-Timop (Canada) & $\begin{array}{l}\text { Timolol maleate } 0.5 \% \\
\text { solution }(6.8 \mathrm{mg} / \mathrm{mL})\end{array}$ & 2 drops dally & $35=1.9$ & $0.48 \pm 0.03^{* *}$ \\
\hline PMS-Timolol (Canada) & $\begin{array}{l}\text { Timolol maleate } 0.5 \% \\
\text { solution }(6.8 \mathrm{mg} / \mathrm{mL})\end{array}$ & 2 drops dally & $29 \div 1.4$ & $0.39 \div 0.02$ \\
\hline Alphagan-P (Canada) & $\begin{array}{l}\text { Brimonidine tartrate } \\
0.15 \%(1.5 \mathrm{mg} / \mathrm{mL})\end{array}$ & 3 drops daily & $46 \pm 1.0$ & $0.21 \pm 0.01$ \\
\hline Apo-Brimonidine-P (Canada) & $\begin{array}{l}\text { Brimonidine tartrate } \\
0.15 \%(1.5 \mathrm{mg} / \mathrm{mL})\end{array}$ & 3 drops daily & $52 \div 1.6$ & $0.23 \pm 0.01$ \\
\hline Alphagan (Canada) & $\begin{array}{l}\text { Brimonidine tartrate } \\
0.2 \%(2.0 \mathrm{mg} / \mathrm{mL})\end{array}$ & 3 drops daily & $32 \pm 2.7$ & $0.20 \pm 0.02$ \\
\hline Apo-Brimonidine (Canada) & $\begin{array}{l}\text { Brimonidine tartrate } \\
0.2 \%(2.0 \mathrm{mg} / \mathrm{mL})\end{array}$ & 3 drops daily & $31 \pm 1.6$ & $0.20 \pm 0.01$ \\
\hline
\end{tabular}

Another important issue is the storage temperature. We know that some medications are more sensible and need to be stored at particular, usually cool temperatures. Kahook et al. reported that the mean concentration of the active ingredient is lower over the time of 30 days by comparing generic version of latanoprost vs. the brand name formulation at different temperatures (fig. 5).
The $\mathrm{pH}$ and osmolarity are not easily recognized by patients. However, patients can easily find differences in labelling, shape of the bottle, drop size, and physical characteristics between a brand product and a generic. These changes can be both an advantage and disadvantage. Frequent changes of the package, the name of the medication, the shape of the bottle and its use, the size of a drop and its viscosity

\section{FIGURE 5}

Mean concentration of the active ingredient of the generic version of latanoprost

vs. the brand name formulation at different temperatures [15].

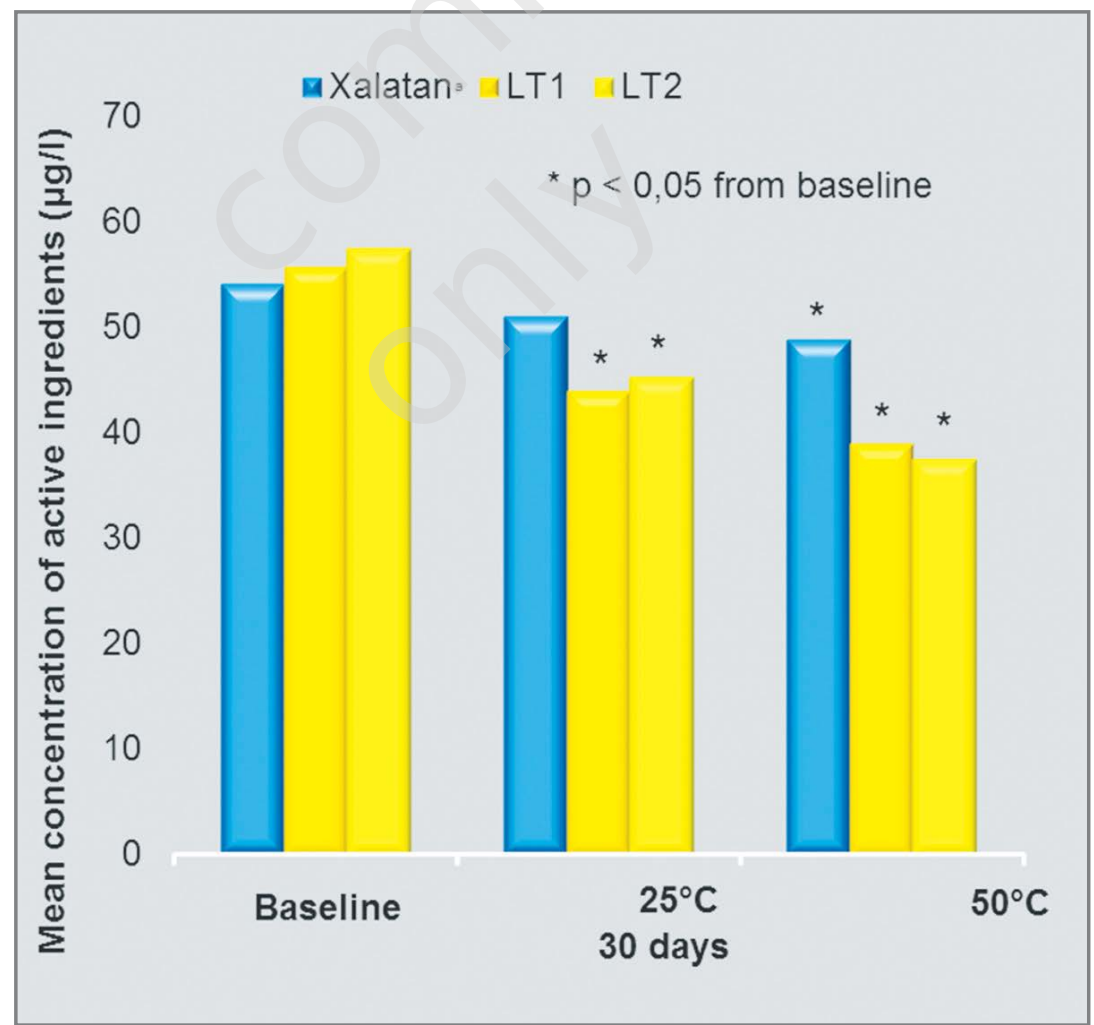


can lead to uncertainty and confusion among (mainly elderly) patients. Doctors should avoid improvident changes in glaucoma medications particularly in treating chronic diseases.

\section{SUMMARY}

There is a significant difference between approving generic topical glaucoma medications and systemic generics. No bioequivalence studies are required for glaucoma drops. A comparable efficacy is expected based on the similar concentration of the active molecule. No randomized clinical trials are required to prove the same efficacy and tolerability in comparison to the original brand product. Due to high costs and long duration we may expect that these studies will not be performed by generic companies.

The potential differences in viscosity, $\mathrm{pH}$, drop size, and surface tension have a potential strong influence on the complex delivery mechanism of the active molecule to the receptors in the eye and its clinical relevant efficacy. These differences, in addition to different appearance and handling of a "new" bottle, may pose problems with patients' compliance.

\section{References}

1. Boimer C, Birt CM. Preservative exposure and surgical outcomes in glaucoma patients: The PESO study. J Glaucoma 2013; 22(9): 730-735. DOI: 10.1097/JJG.0b013e31825af67d.

2. Center for Drug Evaluation and Research. Guidance for Industry: Bioavailability and Bioequivalence Studies for Orally Administered Drug Products - General Considerations. U.S. Department of Health and Human Services Food and Drug Administration 2003.

3. Committee for Medicinal Products for Human Use. Guideline on the Investigation of Bioequivalence. European Medicines Agency 2010 [online: http://www.ema.europa.eu/docs/en_GB/document_library/Scientific_guideline/2009/09/WC500003388.pdf].

4. Holló G, Hommer A. Delivery of Glaucoma Care Committee of the European Glaucoma Society. The status of glaucoma diagnostics and care in Europe in 2015: a European survey. Eur J Ophthalmol 2016; 26(3): 216-220. DOI: 10.5301/ejo.5000699.

5. Kahook M, Fechtner RD, Katz LJ, et al. A comparison of active ingredients and preservatives between brand name and generic topical glaucoma medications using liquid chromatography-tandem mass spectrometry. Curr Eye Res 2012; 37(2): 101-108. DOI: 10.3109/02713683.2011.631722.

6. Leitritz MA, Lipp HP, Voykov B, et al. Original preparations versus generics - latanoprost: how similar is different? Ophthalmologe 2015; 112(2): 127-139. DOI: 10.1007/s00347-014-3097.

7. Mammo ZN, Flanagan JG, James DF, et al. Generic versus brand-name North American topical glaucoma drops. Can J Ophthalmol 2012; 47(1): 55-61. DOI: 10.1016/j.jcjo.2011.12.004.

8. OECD/EU. Health at a Glance: Europe 2014. OECD Publishing, Paris 2014. https://doi.org/10.1787/health_glance_eur-2014-en.

9. Rossetti L, Digiuni M, Giovanni M, et al. Blindness and Glaucoma: A Multicenter Data Review from 7 Academic Eye Clinics. PLoS One 2015; 10(8): e0136632 [online: https://doi.org/10.1371/journal.pone.0136632].

10. Quigley HA. Number of people with glaucoma worldwide. Br J Ophthalmol 1996; 80: 389-393.

11. [online: https://www.eugs.org]. 